\title{
Approaches to Improve the Surveillance, Monitoring, and Management of Noncommunicable Diseases in HIV-Infected Persons: Viewpoint
}

\author{
Pragna Patel ${ }^{1}$, MD, MPH; Keith Sabin ${ }^{2}$, PhD; Peter Godfrey-Faussett ${ }^{3}$, MBBS \\ ${ }^{1}$ Centres for Disease Control and Prevention, Atlanta, GA, United States \\ ${ }^{2}$ Joint United Nations Programme on AIDS, Geneva, Switzerland \\ ${ }^{3}$ Department of Clinical Research, London School of Hygiene and Tropical Medicine, London, United Kingdom
}

Corresponding Author:

Pragna Patel, MD, MPH

Centres for Disease Control and Prevention

1600 Clifton Road

Atlanta, GA, 30333

United States

Phone: 14046396132

Email:plp3@cdc.gov

\begin{abstract}
Low-income and middle-income countries (LMICs) are undergoing an epidemiological transition, in which the burden of noncommunicable diseases (NCDs) is rising and mortality will shift from infectious diseases to NCDs. Specifically, cardiovascular disease, diabetes, renal diseases, chronic respiratory diseases, and cancer are becoming more prevalent. In some regions, particularly sub-Saharan Africa, the dual HIV and NCD epidemics will pose challenges because their joint burden will have adverse effects on the quality of life and will likely increase global inequities. Given the austere clinical infrastructure in many LMICs, innovative models of care delivery are needed to provide comprehensive care in resource-limited settings. Improved data collection and surveillance of NCDs among HIV-infected persons in LMICs are necessary to inform integrated NCD-HIV prevention, care, and treatment models that are effective across a range of geographic settings. These efforts will preserve the considerable investments that have been made to prevent the number of lives lost to HIV, promote healthy aging of persons living with HIV, and contribute to meeting United Nations Sustainable Development Goals.
\end{abstract}

(JMIR Public Health Surveill 2018;4(4):e10989) doi: 10.2196/10989

\section{KEYWORDS}

HIV; noncommunicable diseases; systems integration; epidemiologic surveillance

\section{The HIV and NCD Syndemic}

In high-income countries, antiretroviral therapy (ART) has improved the survival of persons living with HIV (PLHIV), resulting in declines in morbidity and mortality and a shift in the natural history of HIV disease [1-3]. With ART scale-up in the low-income and middle-income countries (LMICs), similar epidemiologic transitions are expected, resulting in an expanding and aging HIV population [4,5]. Since 2004, the US President's Emergency Plan for AIDS Relief (PEPFAR), in collaboration with local governments, has established HIV prevention, care, and treatment programs in over 30 countries worldwide [6], and the Global Fund to Fight HIV, Tuberculosis and Malaria has funded programs in more than 100 countries, including some PEPFAR-funded countries [7]. Globally, the provision of ART accelerated dramatically over the past decade, supporting 19 million PLHIV on ART through June 2016. When the Joint United Nations Programme on AIDS (UNAIDS) [8] 90-90-90 goals $(90 \%$ of people with HIV diagnosed, $90 \%$ of them on ART, and $90 \%$ of them virally suppressed by 2020) are realized, AIDS-related opportunistic infections will become rare [9], and noncommunicable diseases (NCDs) will become increasingly prevalent among PLHIV [10-16].

The natural history of HIV for persons who are stable on ART is that HIV becomes a chronic disease with an increased risk of chronic comorbidities. These chronic conditions include, but are not limited to, cardiovascular disease [17], depression [18-20], cancers [21,22], and metabolic abnormalities, including insulin resistance with consequent dyslipidemia, type 2 diabetes, and lipodystrophy [23-25]. The increased prevalence of NCDs 
among HIV-infected adults reflects a combination of factors, including aging, a greater prevalence of traditional risk factors, infection with oncogenic viruses, direct consequences of HIV (eg, inflammation), and exposure to specific antiretrovirals [26-36]. A recent systematic review examined the prevalences of the following 4 NCDs (and their risk factors) in LMICs that are known to commonly occur among PLHIV: cardiovascular disease, cervical cancer, mental health, and type 2 diabetes [37]. However, data were sparse for some diseases entities.

Increasing patient awareness of the effects of long-term HIV infection and effective levels of antiretroviral treatment, that is, viral suppression, particularly the shift to a predominance of chronic diseases, is important because this improved awareness may prompt patients to report symptoms and request screening for related conditions. Therefore, patient education can improve our ability to detect NCDs as they become more prevalent. An effective public health response to HIV, now that the epidemic is maturing, requires treatment and prevention of NCDs among PLHIV in LMICs. It is imperative to understand the predominant risk factors, the consequent symptoms and complications, and the available appropriate treatments and preventative interventions for each NCD.

If left unaddressed, NCDs may undermine the gains in healthy life-years realized by global health investments in HIV prevention and treatment [38]. The emerging NCD epidemic presents a unique opportunity to leverage the tremendous investments made in the existing HIV health platforms so that these enhanced health systems can deliver improved HIV care, which includes the prevention and treatment of chronic comorbidities to achieve further reductions in preventable deaths. Additionally, lessons learned from the public health approach in response to the HIV epidemic could be applied to the care and treatment of NCDs, given the chronic nature of both conditions. To understand this emerging syndemic, improved surveillance and clinical monitoring of NCDs among PLHIV are necessary to estimate the burden of and risk factors for NCDs among HIV-infected persons.

HIV surveillance has been shifting with the epidemic response over the past 2 decades. Reliance on sentinel surveys and AIDS case reporting was augmented with household surveys, community-based surveys, and HIV case reporting. The current trend is to move toward more routine data collection activities. Patient monitoring systems that capture a variety of health conditions, such as routine perinatal mother-to-child transmission surveillance, are becoming more important as increasing numbers of PLHIV are accessing care and treatment. Some comorbidities are already recognized as important to monitor, though these are primarily infectious, such as tuberculosis, hepatitis B, and hepatitis C. As effective ART continues to be scaled up across LMICs, chronic conditions will become more important to monitor because more PLHIV will achieve virologic suppression.

National HIV program responses would benefit from the integration of screening for NCDs known to be associated with or closely linked to HIV, for example, human papillomavirus-related cancers, such as cervical cancer, and cardiovascular disease [37]. As indicated by a recent systematic review, current efforts are limited to clinical cohorts or studies [37]. Routine screening is not presently being conducted in many clinical settings in sub-Saharan Africa (SSA) that offer HIV care; however, some efforts do exist [39]. General screening could include blood pressure measurement, height and weight assessment, lifestyle counseling including smoking cessation and physical activity promotion, tests for liver and kidney function, and cervical cancer screening. Given the similarities between HIV and NCD care and management, a coordinated approach to address both seems feasible and warranted [40]. Additionally, the resultant health systems' strengthening will facilitate improvements in health care coverage worldwide.

\section{Benefits of Noncommunicable Diseases-HIV Integration}

The PEPFAR HIV program has been criticized as a vertical disease-specific health system with regards to funding, supply chain, and clinician staffing [41-43]. Horizontal integration avoids these issues by taking a multi-disease approach to care $[43,44]$. Models such as chronic disease clinics have proven effective in treating diabetes, hypertension, and HIV and allow caregivers to take a patient-centered approach in responding to the health needs of PLHIV [45]. By preventing late-stage NCD presentation, horizontally-integrated care models minimize NCD-related mortality and may thus maximize costeffectiveness if cost-prudent integration is employed [38]. Integrated models of care have also shown increased retention of patients with comorbid disease, thereby conferring improvements in adherence to treatment and continuity of care [41,43]. Lastly, integration of HIV and NCD monitoring and evaluation (M\&E) systems allows for improved data collection and analysis pertaining to NCDs, which could then be used to support large-scale health policy change [46].

\section{Barriers to Integration}

The integration of NCD and HIV health care can lead to improvements in the quality of care and treatment; however, this enhancement of service provision can be costly. Initial overhead costs needed for service integration include training of clinical staff, procurement and distribution of laboratory reagents and medications, and greater supply chain needs. These costs can often be daunting for policy makers in resource-limited settings [47]. In integrated care systems, deficits in human resources for health, such as limited numbers of health care workers, can become problematic owing to the need for increased requirements for clinical services. Deficits here can lead to bottlenecking because of high patient loads and increased responsibilities for few clinicians [48,49]. Task-shifting can alleviate this bottleneck, but the cost of additional staff and training may be prohibitive.

Economically, integrating NCD care into LMIC HIV systems is only viable with buy-in from the government, external donors, and national constituents. As with PEPFAR for HIV care, countries may require infrastructural capacity building before they become capable of supporting these larger health care 
systems on their own [50]. Although not universally feasible, an ideal solution would entail HIV programs providing the necessary infrastructure for NCD programs with multi-sectoral support and coordination, thus minimizing cost [51]. As countries transition from low-income to middle-income, an additional challenge is finding resources to support HIV programs as donor resources diminish in the face of competing health care demands. These demands include the need for additional financial and human resources in constrained situations. Finally, the integration of separate health systems creates a need for improved management practices. Standards to address selection biases, validity, and reliability of data sources are needed to ensure that robust data are collected. This will ensure that data from a variety of sources (eg, clinical systems, research, and M\&E) are standardized to some extent and will limit missing and unreliable data. M\&E systems must be expanded to include NCD screening and treatment services, and quality of care must be ensured through continued monitoring, evaluation, and medical education $[43,49,52]$.

As NCDs become more prevalent, resource allocation needs to be informed by knowledge of the burden of disease and evidence-based interventions. Cost-effective models of comprehensive care of HIV, a chronic disease when viral suppression is achieved and maintained, that integrates management of NCDs associated with HIV are needed. The first step is leveraging surveillance systems to enhance our knowledge of the NCD burden among PLHIV by collecting information on risk factors and related morbidity. Several strategies to improve knowledge of disease burden exist, allowing public health officials to design or enhance interventions to reduce years of life lost. Among these are case-based surveillance and population-level monitoring systems; registries, which use medical records data for clinical surveillance; cohort monitoring in LMICs; and population-based surveys.

\section{Case-Based Reporting and Population-Level Patient Monitoring Systems}

HIV case reporting has been a part of second generation surveillance, as proposed by the World Health Organization (WHO) and UNAIDS, since 2000 [53]. Case-based reporting systems remain unevenly developed across LMICs [54,55]. The rapid expansion of ART and the promulgation of the 90-90-90 treatment targets have renewed the focus on case reporting, linked to patient monitoring systems, by WHO and UNAIDS. In settings where unique identifiers are available, HIV case report systems can be crossed with registries where they exist to link associated conditions; currently, cancer registries are the most prevalent [56]. Every effort should be made to protect patient privacy and ensure confidentiality as individual systems grow to collect more data elements and are linked to other systems. To strengthen overall patient care, the population-level HIV patient monitoring system, which is designed to track ART adherence and HIV viral suppression, can monitor conditions associated with both HIV infection and long-term exposure to ART. Population-level patient monitoring systems can capture risk factors such as hypertension and hyperlipidemia as well as outcomes such as cardiovascular disease and cancer [57]. Specific conditions that have a demonstrated link to HIV infection or long-term use of ART should be collected and reported, and appropriate responses should be developed for the patient and the population.

\section{Registries}

Registries collect clinical information of all patients diagnosed with a certain condition within a particular catchment area over a period of time and are particularly useful for patient care, especially in areas that lack population-level patient monitoring systems. Patients' information from participating clinics is entered into the registry after diagnosis of a particular NCD or identification of a person with previously diagnosed NCD(s) of interest; this registry contains all patients under the same participating health care provider or in the same facility who have the same NCD. The clinic data collected at each visit is entered into the registry or, ideally, automatically flows from the patients' medical records into the registry without additional resources required for data entry[58]. These data can then be aggregated at the regional or national level and can be used for cohort monitoring; program evaluation; tracking indicators for accountability to funders, policy makers, and stakeholders; and for performance reporting. Furthermore, at the patient level, registries can be used to track adherence, provide reminders for follow-up and preventative services as well as track health changes over time [59].

Registries range from a low-tech paper-based format to a higher-tech electronic format. An electronic medical records (EMRs) system is ideal because it allows for the data to be collected in real-time from a linked EMRs system, and individual or cohort outcomes can be more easily monitored. However, an EMR is not necessary [60]. As the number of cases grows, as expected for an NCD of interest, paper-based registries cannot work efficiently or accurately. Collecting patient data and manually creating a registry is time-consuming and takes health care staff away from patient care [61]. However, it is still a useful modality, and the lack of EMRs systems should not preclude the development of registries, at least in part, for improving patient care.

The creation of registries is important and prudent because the current management of NCDs is, in many places, unstructured and unmonitored. Through the creation of registries, health care systems can gain the ability to collect data on NCDs [62]. Reliable patient data at all levels are necessary for surveillance, forecasting drug and commodity procurement, human resource needs, and logistics required to keep the program on track [63]. However, it is important to ensure that any new data collection requirements render useful information and do not create an additional burden for the health care staff. Registries can also be structured to give feedback on performance, which serves as a benchmark to determine the quality of care and quality improvement at the level of individual providers, health care teams, or clinics. Registries can also be used to support clinical decision making; to allow providers to be proactive rather than reactive, for example, by setting up patient reminders about 
needed services or follow-up visits; and to share data throughout a practice, among practices, and potentially throughout an entire health care system.

Ethical considerations may prevent the inclusion of name-based HIV status in a registry, requiring unique identifiers. However, even with unique identifiers, confidentiality may be lost if systems are not created with checks to ensure privacy. Therefore, precautions to protect the identity of individuals in both name-based HIV case report databases as well as databases that use unique identifiers must be taken, particularly in contexts where stigma and discrimination against PLHIV are strong.

\section{Cohort Monitoring}

An important use of registries is cohort monitoring [64], which is inspired by directly observed treatment, short-course for tuberculosis and provides a useful way of assessing whether interventions, as specified in the country guidelines for NCDs, are being performed as well as to track performance and progress of the intervention. This allows the country to review the progressive scale-up of those alive and on treatment and see where these patients are being treated (hospital, urban health center, rural health center, or private clinic). Furthermore, individual patient data can be deidentified and aggregated to determine morbidity and mortality levels for NCDs generally, generate incidence and prevalence rates of complications, and assess performance at local and national levels [59]. Successful application of the directly observed treatment, short-course monitoring system to patients with diabetes in Malawi [58] and those with hypertension in Jordan [61] has been reported.

\section{Population-Based Surveys}

The WHO-UNAIDS Technical Working Group on HIV Surveillance has advocated the use of population-based surveys to understand the risk factors for HIV and to determine HIV incidence and prevalence. As the HIV epidemic matures in SSA, these surveys should include questions about NCDs and related risk factors. Basic screening for diseases such as hypertension would be easy to employ as well [65]. Household surveys such as the Demographic and Health Surveys (DHS) collect data on screening for NCDs and HIV. Some DHS include testing for NCDs and HIV [66,67]; however, it is uncommon for DHS to routinely report on any associations. These data are publicly available and can be examined for associations, but this should become part of routine public health reporting. Additionally, the WHO STEPwise approach to surveillance should consider an HIV module for high-burden countries. This would allow for both general population and HIV-specific estimates of NCD burden, which would inform national policies and plans to address the growing NCD burden.

The PEPFAR-funded Population-based HIV Impact Assessment surveys are nationally representative, household-based HIV surveys that are used to provide subnational estimates for HIV prevalence and viral load suppression and national estimates for HIV incidence to measure the status of the HIV epidemic and impact of HIV prevention and treatment programs [68]. Data on demographic characteristics, risk behaviors, and testing and treatment history are collected through household and individual questionnaires. These surveys can also be leveraged to collect data about NCDs by including questions about NCD risk factors and diagnosed NCDs. Additionally, HIV testing is routinely performed with laboratory capacity to test blood samples, which provides an opportunity for screening for NCDs as well.

\section{Mathematical Modeling}

Given the limited data currently available concerning the NCD burden among PLHIV in LMICs, mathematical modeling could provide useful information about prevalence. The granularity of the prevalence rates may be limited based on available country-specific data for the models. However, with concerted efforts to collect meaningful data to inform these models, relevant figures could be generated. Currently, the Global Burden of Disease Study generates estimates for the prevalence of various diseases and has a Web-based tool that generates visualizations of these data [69]. As a next step, it may be imperative to develop a tool to generate the estimates of coburden of certain diseases such as HIV and tuberculosis or HIV and cardiovascular disease. Data of coburden can help us to identify syndemics and thus better focus our efforts and resources to prevent and treat these diseases.

\section{Conclusions}

With the success of the global effort to scale up ART access, LMICs, particularly those in SSA, in which mortality has been dominated by HIV over the past decades, will start to experience syndemics. Increasingly, mortality attributable to NCDs will be greater than communicable diseases as it is in the rest of the world. Improved data collection and surveillance of NCDs among HIV-infected persons in LMICs are necessary to inform integrated NCD-HIV prevention, care, and treatment models that are effective across a range of geographic settings. Implementation of integrated care will strengthen current health systems and facilitate a platform for more comprehensive and less fragmented health care delivery as well as M\&E systems. These efforts will preserve the considerable investments that have been made to prevent lives lost to HIV, promote healthy aging of PLHIV, and contribute to meeting United Nations Sustainable Development Goals [70]. Additional incremental investments in NCD management among PLHIV could broaden health care coverage and support a research agenda, which would benefit both PLHIV and the general population. Furthermore, as countries start to achieve HIV epidemic control, the integration of HIV and NCD management will provide a transition plan for extending the comprehensive care provided to PLHIV to the general population; this will facilitate the goal of improved overall access to health care. 


\section{Acknowledgments}

The findings and conclusions in this report are those of the authors and do not necessarily represent the official position of the funding agencies.

\section{Conflicts of Interest}

None declared.

\section{References}

1. HIV-CAUSAL Collaboration, Ray M, Logan R, Sterne JAC, Hernández-Díaz S, Robins JM, et al. The effect of combined antiretroviral therapy on the overall mortality of HIV-infected individuals. AIDS 2010 Jan 02;24(1):123-137 [FREE Full text] [doi: 10.1097/QAD.0b013e3283324283] [Medline: 19770621$]$

2. Antiretroviral TCC. Life expectancy of individuals on combination antiretroviral therapy in high-income countries: a collaborative analysis of 14 cohort studies. The Lancet 2008 Jul;372(9635):293-299. [doi: 10.1016/S0140-6736(08)61113-7]

3. Bhaskaran K, Hamouda O, Sannes M, Boufassa F, Johnson A, Lambert P, CASCADE Collaboration. Changes in the risk of death after HIV seroconversion compared with mortality in the general population. JAMA 2008 Jul 02;300(1):51-59. [doi: 10.1001/jama.300.1.51] [Medline: $\underline{18594040]}$

4. Patel R, Moore T, Cooper V, McArdle C, Perry N, Cheek E, et al. An observational study of comorbidity and healthcare utilisation among HIV-positive patients aged 50 years and over. Int J STD AIDS 2016 Dec;27(8):628-637. [doi: 10.1177/0956462415589524] [Medline: 26068965]

5. Kalima M, Lishimpi K, Meza J, Watanabe-Galloway S, Msadabwe S, Mwaba C, et al. Observed and expected incidence of cervical cancer in lusaka and the southern and Western provinces of Zambia, 2007 to 2012. Int J Gynecol Cancer 2015 Jan;25(1):98-105 [FREE Full text] [doi: 10.1097/IGC.0000000000000325] [Medline: 25423318]

6. The United States President's Emergency Plan for AIDS Relief. 2018. URL: https://www.pepfar.gov/ [accessed 2018-08-13] [WebCite Cache ID 71eAvS9Z1]

7. The Global Fund. URL: https://www.theglobalfund.org/en/ [accessed 2018-08-13] [WebCite Cache ID 71eB3dacP]

8. United Nations Programme on AIDS. Ending the AIDS Epidemic by 2030 URL: http://www.unaids.org/ [accessed 2018-08-13] [WebCite Cache ID 71eBDXFF3]

9. Buchacz K, Baker R, Palella F, Chmiel J, Lichtenstein K, Novak R, HOPS Investigators. AIDS-defining opportunistic illnesses in US patients, 1994-2007: a cohort study. AIDS 2010 Jun 19;24(10):1549-1559. [doi: 10.1097/QAD.0b013e32833a3967] [Medline: 20502317]

10. Ferry T, Raffi F, Collin-Filleul F, Dupon M, Dellamonica P, Waldner A, et al. Uncontrolled Viral Replication as a Risk Factor for Non-AIDS Severe Clinical Events in HIV-Infected Patients on Long-Term Antiretroviral Therapy: APROCO/COPILOTE (ANRS CO8) Cohort Study. JAIDS Journal of Acquired Immune Deficiency Syndromes 2009;51(4):407-415. [doi: 10.1097/QAI.0b013e3181acb65f]

11. Deeks SG, Phillips AN. HIV infection, antiretroviral treatment, ageing, and non-AIDS related morbidity. BMJ 2009 Jan 26;338:a3172. [doi: 10.1136/bmj.a3172] [Medline: 19171560]

12. Goulet JL, Fultz SL, Rimland D, Butt A, Gibert C, Rodriguez-Barradas M, et al. Aging and infectious diseases: do patterns of comorbidity vary by HIV status, age, and HIV severity? Clin Infect Dis 2007 Dec 15;45(12):1593-1601 [FREE Full text] [doi: 10.1086/523577] [Medline: 18190322]

13. Moore RD, Gebo KA, Lucas GM, Keruly JC. Rate of comorbidities not related to HIV infection or AIDS among HIV-infected patients, by CD4 cell count and HAART use status. Clin Infect Dis 2008 Oct 15;47(8):1102-1104 [FREE Full text] [doi: 10.1086/592115] [Medline: 18781885]

14. Mocroft A, Reiss P, Gasiorowski J, Ledergerber B, Kowalska J, Chiesi A, EuroSIDA Study Group. Serious fatal and nonfatal non-AIDS-defining illnesses in Europe. J Acquir Immune Defic Syndr 2010 Oct;55(2):262-270. [doi: 10.1097/QAI.0b013e3181e9be6b] [Medline: 20700060]

15. French A, Gawel S, Hershow R, Benning L, Hessol N, Levine A, et al. Trends in mortality and causes of death among women with HIV in the United States: a 10-year study. J Acquir Immune Defic Syndr 2009 Aug 01;51(4):399-406 [FREE Full text] [doi: 10.1097/QAI.0b013e3181acb4e5] [Medline: 19487953]

16. Onen N, Overton E, Seyfried W, Stumm E, Snell M, Mondy K, et al. Aging and HIV infection: a comparison between older HIV-infected persons and the general population. HIV Clin Trials 2010;11(2):100-109. [doi: 10.1310/hct1102-100] [Medline: 20542846]

17. Kingsley LA, Cuervo-Rojas J, Muñoz A, Palella FJ, Post W, Witt MD, et al. Subclinical coronary atherosclerosis, HIV infection and antiretroviral therapy: Multicenter AIDS Cohort Study. AIDS 2008 Aug 20;22(13):1589-1599 [FREE Full text] [doi: 10.1097/QAD.0b013e328306a6c5] [Medline: 18670218]

18. Bing E, Burnam M, Longshore D, Fleishman J, Sherbourne C, London A, et al. Psychiatric disorders and drug use among human immunodeficiency virus-infected adults in the United States. Arch Gen Psychiatry 2001 Aug;58(8):721-728. [Medline: 11483137$]$ 
19. Ciesla J, Roberts J. Meta-analysis of the relationship between HIV infection and risk for depressive disorders. Am J Psychiatry 2001 May;158(5):725-730. [doi: 10.1176/appi.ajp.158.5.725] [Medline: 11329393]

20. Tsai AC. Reliability and validity of depression assessment among persons with HIV in sub-Saharan Africa: systematic review and meta-analysis. J Acquir Immune Defic Syndr 2014 Aug 15;66(5):503-511 [FREE Full text] [doi: 10.1097/QAI.0000000000000210] [Medline: 24853307]

21. Crum-Cianflone N, Hullsiek KH, Marconi V, Weintrob A, Ganesan A, Barthel RV, et al. Trends in the incidence of cancers among HIV-infected persons and the impact of antiretroviral therapy: a 20-year cohort study. AIDS 2009 Jan 02;23(1):41-50 [FREE Full text] [doi: 10.1097/QAD.0b013e328317cc2d] [Medline: 19050385]

22. Patel P, Hanson DL, Sullivan PS, Novak RM, Moorman AC, Tong TC, AdultAdolescent Spectrum of Disease ProjectHIV Outpatient Study Investigators. Incidence of types of cancer among HIV-infected persons compared with the general population in the United States, 1992-2003. Ann Intern Med 2008 May 20;148(10):728-736. [Medline: 18490686]

23. Worm S, De Wit S, Weber R, Sabin C, Reiss P, El-Sadr W, et al. Diabetes mellitus, preexisting coronary heart disease, and the risk of subsequent coronary heart disease events in patients infected with human immunodeficiency virus: the Data Collection on Adverse Events of Anti-HIV Drugs (D:A:D Study). Circulation 2009 Feb 17;119(6):805-811 [FREE Full text] [doi: 10.1161/CIRCULATIONAHA.108.790857] [Medline: 19188509]

24. Neuhaus J, Jacobs DR, Baker JV, Calmy A, Duprez D, La Rosa A, et al. Markers of inflammation, coagulation, and renal function are elevated in adults with HIV infection. J Infect Dis 2010 Jun 15;201(12):1788-1795 [FREE Full text] [doi: 10.1086/652749] [Medline: 20446848]

25. Wand H, Calmy A, Carey DL, Samaras K, Carr A, Law MG, INITIO Trial International Coordinating Committee. Metabolic syndrome, cardiovascular disease and type 2 diabetes mellitus after initiation of antiretroviral therapy in HIV infection. AIDS 2007 Nov 30;21(18):2445-2453. [doi: 10.1097/QAD.0b013e3282efad32] [Medline: 18025881]

26. Deeks SG. Immune dysfunction, inflammation, and accelerated aging in patients on antiretroviral therapy. Top HIV Med 2009;17(4):118-123 [FREE Full text] [Medline: 19890183]

27. Lau B, Gange SJ, Moore RD. Risk of non-AIDS-related mortality may exceed risk of AIDS-related mortality among individuals enrolling into care with CD4+ counts greater than 200 cells/mm3. J Acquir Immune Defic Syndr 2007 Feb 01;44(2):179-187. [doi: 10.1097/01.qai.0000247229.68246.c5] [Medline: $\underline{17075385]}$

28. Study Group DAD, Friis-Møller N, Reiss P, Sabin CA, Weber R, Monforte AD, et al. Class of antiretroviral drugs and the risk of myocardial infarction. N Engl J Med 2007 Apr 26;356(17):1723-1735. [doi: 10.1056/NEJMoa062744] [Medline: 17460226]

29. Carr A. HIV lipodystrophy: risk factors, pathogenesis, diagnosis and management. AIDS 2003 Apr;17 Suppl 1:S141-S148. [Medline: 12870540$]$

30. Anastos K, Lu D, Shi Q, Tien PC, Kaplan RC, Hessol NA, et al. Association of serum lipid levels with HIV serostatus, specific antiretroviral agents, and treatment regimens. J Acquir Immune Defic Syndr 2007 May 01;45(1):34-42. [doi: 10.1097/QAI.0b013e318042d5fe] [Medline: 17460470]

31. Hessol NA, Kalinowski A, Benning L, Mullen J, Young M, Palella F, et al. Mortality among participants in the Multicenter AIDS Cohort Study and the Women's Interagency HIV Study. Clin Infect Dis 2007 Jan 15;44(2):287-294. [doi: 10.1086/510488] [Medline: 17173233]

32. Lichtenstein KA, Armon C, Buchacz K, Chmiel JS, Buckner K, Tedaldi EM, HIV Outpatient Study (HOPS) Investigators. Low CD4+ T cell count is a risk factor for cardiovascular disease events in the HIV outpatient study. Clin Infect Dis 2010 Aug 15;51(4):435-447. [doi: 10.1086/655144] [Medline: 20597691]

33. Savès M, Chêne G, Ducimetière P, Leport C, Le Moal G, Amouyel P, French WHO MONICA Projectthe APROCO (ANRS EP11) Study Group. Risk factors for coronary heart disease in patients treated for human immunodeficiency virus infection compared with the general population. Clin Infect Dis 2003 Jul 15;37(2):292-298. [doi: 10.1086/375844] [Medline: 12856222]

34. Study Group D, Friis-Møller N, Reiss P, Sabin CA, Weber R, Monforte AD, et al. Class of antiretroviral drugs and the risk of myocardial infarction. N Engl J Med 2007 Apr 26;356(17):1723-1735. [doi: 10.1056/NEJMoa062744] [Medline: $\underline{17460226]}$

35. Holmberg S, Moorman A, Williamson J, Tong T, Ward D, Wood K, et al. Protease inhibitors and cardiovascular outcomes in patients with HIV-1. The Lancet 2002 Nov;360(9347):1747-1748. [doi: 10.1016/S0140-6736(02)11672-2]

36. Grinspoon S, Carr A. Cardiovascular risk and body-fat abnormalities in HIV-infected adults. N Engl J Med 2005 Jan 06;352(1):48-62. [doi: 10.1056/NEJMra041811] [Medline: 15635112]

37. Patel P, Rose CE, Collins PY, Nuche-Berenguer B, Sahasrabuddhe VV, Peprah E, NIH HIV/NCD Project Disease Condition Technical Operating Group. Noncommunicable diseases among HIV-infected persons in low-income and middle-income countries: a systematic review and meta-analysis. AIDS 2018 Jul 01;32 Suppl 1:S5-S20. [doi: 10.1097/QAD.0000000000001888] [Medline: 29952786]

38. Council on Foreign Relations. The emerging global health crisis: noncommunicable diseases in low- and middle-income countries URL: https://www.cfr.org/report/emerging-global-health-crisis?co=C007301 [accessed 2018-11-05] [WebCite Cache ID 73iM92EPb] 
39. Njuguna B, Vorkoper S, Patel P, Reid MJA, Vedanthan R, Pfaff C, et al. Models of integration of HIV and noncommunicable disease care in sub-Saharan Africa: lessons learned and evidence gaps. AIDS 2018 Jul 01;32 Suppl 1:S33-S42. [doi: 10.1097/QAD.0000000000001887] [Medline: 29952788]

40. Oti S. HIV and noncommunicable diseases: a case for health system building. Curr Opin HIV AIDS 2013 Jan;8(1):65-69. [doi: 10.1097/COH.0b013e32835b8088] [Medline: 23143141]

41. Nigatu T. Integration of HIV and noncommunicable diseases in health care delivery in low- and middle-income countries. Prev Chronic Dis 2012;9:E93 [FREE Full text] [Medline: 22554408]

42. Schwartz JI, Dunkle A, Akiteng AR, Birabwa-Male D, Kagimu R, Mondo CK, et al. Towards reframing health service delivery in Uganda: the Uganda Initiative for Integrated Management of Non-Communicable Diseases. Glob Health Action 2015;8:26537 [FREE Full text] [doi: 10.3402/gha.v8.26537] [Medline: 25563451]

43. Levitt N, Steyn K, Dave J, Bradshaw D. Chronic noncommunicable diseases and HIV-AIDS on a collision course: relevance for health care delivery, particularly in low-resource settings--insights from South Africa. Am J Clin Nutr 2011

Dec;94(6):1690S-1696S [FREE Full text] [doi: 10.3945/ajcn.111.019075] [Medline: 22089433]

44. Briggs C, Garner P. Strategies for integrating primary health services in middle- and low-income countries at the point of delivery. Cochrane Database Syst Rev 2006 Apr 19;2(2):CD003318. [doi: 10.1002/14651858.CD003318.pub2] [Medline: 16625576]

45. Janssens B, Van Damme W, Raleigh B, Gupta J, Khem S, Soy Ty K, et al. Offering integrated care for HIV/AIDS, diabetes and hypertension within chronic disease clinics in Cambodia. Bull World Health Organ 2007 Nov;85(11):880-885 [FREE Full text] [Medline: 18038079]

46. Atun R, Jaffar S, Nishtar S, Knaul FM, Barreto ML, Nyirenda M, et al. Improving responsiveness of health systems to non-communicable diseases. Lancet 2013 Feb 23;381(9867):690-697. [doi: 10.1016/S0140-6736(13)60063-X] [Medline: 23410609]

47. Package of Essential Noncommunicable Disease Interventions for Primary Healthcare in Low-Resource Settings. Geneva, Switzerland: World Health Organization; 2010. URL: https://www.who.int/nmh/publications/ essential_ncd_interventions_lr_settings.pdf [accessed 2018-11-05] [WebCite Cache ID 73iMnmKvm]

48. Petersen I, Lund C, Bhana A, Flisher AJ, Mental HealthPoverty Research Programme Consortium. A task shifting approach to primary mental health care for adults in South Africa: human resource requirements and costs for rural settings. Health Policy Plan 2012 Jan;27(1):42-51. [doi: 10.1093/heapol/czr012] [Medline: 21325270]

49. Mall S, Sorsdahl K, Swartz L, Joska J. "I understand just a little...” Perspectives of HIV/AIDS service providers in South Africa of providing mental health care for people living with HIV/AIDS. AIDS Care 2012;24(3):319-323. [doi: 10.1080/09540121.2011.608790] [Medline: 22273005]

50. Bollyky T. Preventing Pharmageddon: Treatment Access for Non-communicable Diseases. Policy Innovation Memorandum No 32: Council on Foreign Relations; 2013. URL: https://www.cfr.org/report/ preventing-pharmageddon-treatment-access-noncommunicable-diseases [accessed 2018-11-05] [WebCite Cache ID 73iMx7YZk]

51. Hyle E, Naidoo K, Su AE, El-Sadr WM, Freedberg KA. HIV, tuberculosis, and noncommunicable diseases: what is known about the costs, effects, and cost-effectiveness of integrated care? J Acquir Immune Defic Syndr 2014 Sep 01;67 Suppl 1:S87-S95 [FREE Full text] [doi: 10.1097/QAI.0000000000000254] [Medline: 25117965]

52. Adebamowo CA, Casper C, Bhatia K, Mbulaiteye SM, Sasco AJ, Phipps W, et al. Challenges in the detection, prevention, and treatment of HIV-associated malignancies in low- and middle-income countries in Africa. J Acquir Immune Defic Syndr 2014 Sep 01;67 Suppl 1:S17-S26 [FREE Full text] [doi: 10.1097/QAI.0000000000000255] [Medline: 25117957]

53. Consolidated guidelines on person-centered HIV monitoring and case surveillance. Geneva, Switzerland: World Health Organization; 2002. URL: http://www.who.int/sorry/ [accessed 2018-11-05] [WebCite Cache ID 73iN6H9c3]

54. Harklerode R, Schwarcz S, Hargreaves J, Boulle A, Todd J, Xueref S, et al. Feasibility of Establishing HIV Case-Based Surveillance to Measure Progress Along the Health Sector Cascade: Situational Assessments in Tanzania, South Africa, and Kenya. JMIR Public Health Surveill 2017 Jul 10;3(3):e44 [FREE Full text] [doi: 10.2196/publichealth.7610] [Medline: $\underline{28694240]}$

55. Rice B, Boulle A, Baral S, Egger M, Mee P, Fearon E, et al. Strengthening Routine Data Systems to Track the HIV Epidemic and Guide the Response in Sub-Saharan Africa. JMIR Public Health Surveill 2018 Apr 03;4(2):e36 [FREE Full text] [doi: 10.2196/publichealth.9344] [Medline: 29615387]

56. Godbole SV, Nandy K, Gauniyal M, Nalawade P, Sane S, Koyande S, et al. HIV and cancer registry linkage identifies a substantial burden of cancers in persons with HIV in India. Medicine (Baltimore) 2016 Sep;95(37):e4850 [FREE Full text] [doi: 10.1097/MD.0000000000004850] [Medline: 27631245]

57. Nawi N, Hoang VM, Sanjay J, Abdur R, Tran HB, Uraiwan K, et al. Using the INDEPTH HDSS to build capacity for chronic non-communicable disease risk factor surveillance in low and middle-income countries. Global Health Action 2009 [FREE Full text] [doi: 10.3402/gha.v2i0.1984]

58. Bodenheimer T, Wagner EH, Grumbach K. Improving primary care for patients with chronic illness. JAMA 2002 Oct 09;288(14):1775-1779. [Medline: 12365965] 
59. Innovative care for chronic conditions: building blocks for action: global report. Geneva, Switzerland: World Health Organization; 2002. URL: http://www.who.int/chp/knowledge/publications/icccglobalreport.pdf [accessed 2018-11-05] [WebCite Cache ID 73iNy7Exe]

60. Allain TJ, van Oosterhout JJ, Douglas GP, Joukes S, Gadabu OJ, Darts C, et al. Applying lessons learnt from the 'DOTS' Tuberculosis Model to monitoring and evaluating persons with diabetes mellitus in Blantyre, Malawi. Trop Med Int Health 2011 Sep;16(9):1077-1084 [FREE Full text] [doi: 10.1111/j.1365-3156.2011.02808.x] [Medline: 21702868]

61. Khader A, Farajallah L, Shahin Y, Hababeh M, Abu-Zayed I, Kochi A, et al. Cohort monitoring of persons with hypertension: an illustrated example from a primary healthcare clinic for Palestine refugees in Jordan. Trop Med Int Health 2012 Sep;17(9):1163-1170 [FREE Full text] [doi: 10.1111/j.1365-3156.2012.03048.x] [Medline: 22845700]

62. Harries AD, Jahn A, Zachariah R, Enarson D. Adapting the DOTS framework for tuberculosis control to the management of non-communicable diseases in sub-Saharan Africa. PLoS Med 2008 Jun 10;5(6):e124 [FREE Full text] [doi:

10.1371/journal.pmed.0050124] [Medline: 18547138]

63. Harries AD, Kumar AMV, Karpati A, Jahn A, Douglas GP, Gadabu OJ, et al. Monitoring treatment outcomes in patients with chronic disease: lessons from tuberculosis and HIV/AIDS care and treatment programmes. Trop Med Int Health 2015 Jul;20(7):961-964 [FREE Full text] [doi: 10.1111/tmi.12506] [Medline: 25779103]

64. Maher D. The Power of Health Information-the Use of Cohort Monitoring in Managing Patients with Chronic Non-Communicable Diseases. Tropical Medicine and International Health 2012 Dec 01;17(12):1568-3156. [doi: 10.1111/j.1365-3156.2012.03094.x ]

65. Day C, Groenewald P, Laubscher R, Chaudhry S, Van Schaik N, Bradshaw D. Monitoring of non-communicable diseases such as hypertension in South Africa: Challenges for the post-2015 global development agenda. S Afr Med J 2014 Aug 13;104(10):680. [doi: 10.7196/samj.7868]

66. Lesotho Demographic and Health Survey 2009. Maseru, Lesotho: Ministry of Health and Social Welfare; 2009. URL: https://dhsprogram.com/pubs/pdf/FR241/FR241.pdf [accessed 2018-11-05] [WebCite Cache ID 73iUUFSgW]

67. Kenya Demographic and Health Survey 2014. Nairobi, Kenya: Kenya National Bureau of Statistics; 2015. URL: https:/ /dhsprogram.com/pubs/pdf/FR308/FR308.pdf [accessed 2018-11-05] [WebCite Cache ID 73iUYpSEV]

68. Justman J. Real Progress in the HIV Epidemic: PHIA findings from Zimbabwe, Malawi, and Zambia. 2017 Feb 13 Presented at: Conference on Retroviruses and Opportunistic Infections. Abstract \#LB114; 2017; Seattle, Washington p. 13-16.

69. Global Health Data Exchange. 2018. Institute for Health Metrics and Evaluation URL: $\underline{\text { http://ghdx.healthdata.org/gbd-2016 }}$ [accessed 2018-08-13] [WebCite Cache ID 71eDTm5o1]

70. Sustainable Development Goals.: United Nations; 2018. About the Sustainable Development Goals URL: https://www. un.org/sustainabledevelopment/sustainable-development-goals/ [accessed 2018-08-13] [WebCite Cache ID 71eBOOpxQ]

\author{
Abbreviations \\ ART: antiretroviral therapy \\ DHS: Demographic and Health Surveys \\ EMR: electronic medical record \\ LMIC: low-income and middle-income countries \\ M\&E: monitoring and evaluation \\ NCD: noncommunicable diseases \\ PEPFAR: President's Emergency Plan for AIDS Relief \\ PLHIV: persons living with HIV \\ SSA: sub-Saharan Africa \\ UNAIDS: Joint United Nations Programme on AIDS \\ WHO: World Health Organization
}

Edited by B Rice; submitted 07.05.18; peer-reviewed by L Kupfer, L Ti, B Honermann; comments to author 26.06.18; revised version
received 13.08.18; accepted 20.09.18; published 20.12.18
Please cite as:
Patel P, Sabin K, Godfrey-Faussett P
Approaches to Improve the Surveillance, Monitoring, and Management of Noncommunicable Diseases in HIV-Infected Persons:
Viewpoint
JMIR Public Health Surveill 2018;4(4):e10989
URL: $\underline{\text { http://publichealth.jmir.org/2018/4/e10989/ }}$
doi: $\underline{10.2196 / 10989}$
PMID: $\underline{30573446}$


CPragna Patel, Keith Sabin, Peter Godfrey-Faussett. Originally published in JMIR Public Health and Surveillance (http://publichealth.jmir.org), 20.12.2018. This is an open-access article distributed under the terms of the Creative Commons Attribution License (https://creativecommons.org/licenses/by/4.0/), which permits unrestricted use, distribution, and reproduction in any medium, provided the original work, first published in JMIR Public Health and Surveillance, is properly cited. The complete bibliographic information, a link to the original publication on http://publichealth.jmir.org, as well as this copyright and license information must be included. 